\title{
TGF- $\beta 1$ Impairs Vitamin D-Induced and Constitutive Airway Epithelial Host Defense Mechanisms
}

\author{
Jasmijn A. Schrumpf Dennis K. Ninaber Anne M. van der Does \\ Pieter S. Hiemstra \\ Department of Pulmonology, Leiden University Medical Center, Leiden, The Netherlands
}

\section{Keywords}

Airway epithelial cells · Vitamin D · TGF- $\beta 1 \cdot$ hCAP18/LL-37 . Host defense

\begin{abstract}
Airway epithelium is an important site for local vitamin D (VD) metabolism; this can be negatively affected by inflammatory mediators. VD is an important regulator of respiratory host defense, for example, by increasing the expression of hCAP18/LL-37. TGF- $\beta 1$ is increased in chronic obstructive pulmonary disease (COPD), and known to decrease the expression of constitutive host defense mediators such as secretory leukocyte protease inhibitor (SLPI) and polymeric immunoglobulin receptor (plgR). VD has been shown to affect TGF- $\beta 1$-signaling by inhibiting TGF- $\beta 1$-induced epithelialto-mesenchymal transition. However, interactions between VD and TGF- $\beta 1$, relevant for the understanding host defense in COPD, are incompletely understood. Therefore, the aim of the present study was to investigate the combined effects of VD and TGF- $\beta 1$ on airway epithelial cell host defense mechanisms. Exposure to TGF- $\beta 1$ reduced both baseline and VD-
\end{abstract}

\begin{tabular}{ll}
\hline KARGER & $\begin{array}{l}\text { (c) } 2019 \text { The Author(s) } \\
\text { Published by S. Karger AG, Basel }\end{array}$ \\
E-Mail karger@karger.com & This article is licensed under the Creative Commons Attribution- \\
www.karger.com/jin & NonCommercial-NoDerivatives 4.0 International License (CC BY- \\
& NC-ND) (http://www.karger.com/Services/OpenAccessLicense). \\
Usage and distribution for commercial purposes as well as any dis- \\
tribution of modified material requires written permission.
\end{tabular}

induced expression of hCAP18/LL-37, partly by increasing the expression of the VD-degrading enzyme CYP24A1. TGF- $\beta 1$ alone decreased the number of secretory club and goblet cells and reduced the expression of constitutive host defense mediators SLPI, s/IPLUNC and plgR, effects that were not modulated by VD. These results suggest that TGF- $\beta 1$ may decrease the respiratory host defense both directly by reducing the expression of host defense mediators, and indirectly by affecting VD-mediated effects such as expression of hCAP18/LL-37.

(c) 2019 The Author(s)

Published by S. Karger AG, Basel

\section{Introduction}

Patients with chronic obstructive pulmonary disease (COPD) suffer more frequently from respiratory infections than ex- or non-smokers, and this may contribute to exacerbations and to the further progression of the disease $[1,2]$. This increased susceptibility to infections can be explained by impaired mucociliary clearance and de- 
creased host defense [3], that may in part result from persistent exposure to cigarette smoke (CS) or to other noxious gases [4-6]. The airway epithelium serves as the front line in the lung's host defense by preventing microbes from entering the tissue and bloodstream. Its contribution to this important function is mediated by a combination of mechanisms including (but not limited to) the maintenance of a physical barrier supported by its tightand adherens junctions, mucociliary clearance, and secretion of both inducible and constitutively expressed host defense peptides and proteins (HDPs), reactive oxygen- and nitrogen species, interferons, chemokines, and cytokines [7]. In addition to broad-spectrum antimicrobial activity, HDPs also have the ability to modulate immune responses and promote wound repair [8]. Under homeostasis, inducible HDPs such as human $\beta$-defensin-2 and hCAP18/LL-37 are expressed at low levels and their expression can be increased upon, for example, activation of pattern recognition receptors [9], cytokine and growth factor receptors, and by other mediators such as vitamin D (VD), whereas constitutively expressed HDPs do not require such stimuli for their expression [9-11].

Whereas VD is classically known for its function in the regulation of calcium homeostasis and bone metabolism, multiple studies have shown that it also acts as an important regulator of host defense and immunity, including respiratory host defense $[12,13]$. This was supported by 2 clinical trials that showed that VD supplementation reduces the exacerbation rate in VD-deficient COPD patients $[14,15]$ and a recent meta-analysis that demonstrated that VD supplementation protects against acute respiratory tract infections [16]. Various mechanisms may contribute to this protective effect of $\mathrm{VD}$, including direct effects such as VD-mediated increases of hCAP18/ LL-37, and/or indirect effects via promotion of CFTR expression or its ability to reduce oxidative stress $[11,17-$ 19]. In the airway epithelium, the main circulating form of $\left.\mathrm{VD}(25[\mathrm{OH})] \mathrm{D}_{3}\right)$ is hydroxylated to generate the active form of VD $\left(1,25[\mathrm{OH}]_{2} \mathrm{D}_{3}\right)$ by a1-hydroxylase (cytochrome P [CYP] 27B1) [20]. Next, $1,25(\mathrm{OH})_{2} \mathrm{D}_{3}$ binds the nuclear VD receptor (VDR) and heterodimerizes with the retinoic acid receptor to interact with VD response elements to initiate gene expression of more than 900 genes, including CYP24A1, which converts both $25(\mathrm{OH}) \mathrm{D}_{3}$ and $1,25(\mathrm{OH})_{2} \mathrm{D}_{3}$ into inactive metabolites $[12,21]$. The airway epithelium is an important site of local VD metabolism and we and others have shown that the expression or the activity of CYP27B1, CYP24A1, and VDR can be modulated by several inflammatory mediators such as TNF- $\alpha /$ IL-1 $\beta$, IL-17A, non-typeable Haemophilus influ- enzae (NTHi), IL-13, the viral analog poly(I:C) and CS, which have been implicated in the pathogenesis of chronic inflammatory lung diseases $[5,20,22,23]$.

Studies in prostate cancer and stromal cells and hepatocytes suggest that the positive effects of VD might be modulated by TGF- $\beta 1[24,25]$. This may be relevant for COPD, since elevated levels of TGF- $\beta 1$ expression were found in the airways of COPD patients [26-28], although this was not shown by all studies [29]. TGF- $\beta 1$ is a multifunctional cytokine that is produced and activated upon injury, through CS-exposure or by inflammation [3033]. When this injury persists, continued release of TGF- $\beta 1$ contributes to tissue remodeling, a process that may be driven in part by epithelial-to-mesenchymal transition (EMT) [34]. Several studies have shown that VD might counteract TGF- $\beta 1$-mediated effects on fibrosis, as demonstrated by its ability to inhibit TGF- $\beta 1$-induced EMT in both mouse models of asthma and fibrosis and in airway epithelial cell lines [17, 35-37]. In addition to its role in fibrosis and EMT, TGF- $\beta 1$ affects respiratory host defense by impairing anti-viral interferon type I and III responses, but also by restricting the expression of constitutively expressed host defense mediators such as secretory leukocyte protease inhibitor (SLPI) and polymeric immunoglobulin receptor (pIgR) [31, 32, 38, 39].

Despite this insight into the role of TGF- $\beta 1$ in the pathogenesis of COPD and other chronic inflammatory lung disease, it is not known whether exposure to TGF- $\beta 1$ also affects respiratory host defense by affecting VD-metabolism and VD-mediated expression of the HDP hCAP18/LL-37. Moreover, it is currently unknown whether VD modulates TGF- $\beta 1$-mediated repression of constitutively expressed HDPs. We therefore aimed to study the interaction between VD and TGF- $\beta 1$ on airway epithelial cell host defense mechanisms. To this end, we first investigated the effects and underlying mechanisms ofTGF- $\beta 1$ on VD-metabolism on VD-mediated hCAP18/ LL-37 expression. Next, we studied the effects of VD on TGF- $\beta 1$-induced changes in epithelial composition and on expression of a group of constitutively expressed host defense mediators, as well as on antibacterial activity.

\section{Materials and Methods}

Primary Bronchial Epithelial Cell Culture

Primary Bronchial Epithelial Cells (PBEC) were obtained from tumor-free bronchial lung tissue from anonymous donors during lung resection surgery for lung cancer at LUMC. Cells were cultured, as previously described, with some adaptations $[5,40]$. Briefly, cultures of bronchial epithelial cells (passage 1) were first ex- 
Table 1. PCR primers and sequences used for $\mathrm{qPCR}$

\begin{tabular}{|c|c|c|c|c|}
\hline Gene & Encoding protein & Sequence forward primer & Sequence reverse primer & $\begin{array}{l}\text { GenBank accession } \\
\text { number }\end{array}$ \\
\hline YWHAZ* & $\begin{array}{l}\text { Tyrosine 3-monooxygenase/tryptophan } \\
\text { 5-monooxygenase activation protein zeta }\end{array}$ & ACTTTTGGTACATTGTGGCTTCAA & CCGCCAGGACAAACCAGTAT & NM_001135699.1 \\
\hline RPL27* & Ribosomal protein $\mathrm{L} 27$ & ATCGCCAAGAGATCAAAGATAA & TCTGAAGACATCCTTATTGACG & NM_000988 \\
\hline CAMP & hCAP18/LL-37 & TCATTGCCCAGGTCCTCAG & TCCCCATACACCGCTTCAC & NM_004345.3 \\
\hline CYP24A1 & 24-hydroxylase & TTGGCTCTTTGTTGGATTGTCCGC & TGAAGATGGTGCTGACACAGGTGA & NM_000782.3 \\
\hline CYP27B1 & a1-hydroxylase & AACCCTGAACAACGTAGTCTGCGA & ATGGTCAACAGCGTGGACACAAA & NM_000785.3 \\
\hline$V D R$ & Vitamin D receptor & ACCTGGTCAGTTACAGCATCC & TGGTGAAGGACTCATTGGAGC & NM_001017535.1 \\
\hline SLPI & Secretory leukocyte protease inhibitor & GAGATGTTGTCCTGACACTTGTG & AGGCTTCCTCCTTGTTGGGT & NM_003064 \\
\hline BPIFA1 & Short palate, lung, and nasal epithelium clone protein & CTTGGCCTTGTGCAGAGC & CAACAGACTTGCACCGACC & NM_016583 \\
\hline BPIFA2 & Long palate, lung, and nasal epithelium clone protein & CAGTGCCATGCGGGAAAAG & GCTGGAGGATGTTAGCTGTGA & NM_080574 \\
\hline PIGR & Polymeric Immunoglobulin receptor & CTCTCTGGAGGACCACCGT & CAGCCGTGACATTCCCTG & NM_002644 \\
\hline CLCA1 & Chloride channel accessory 1 & ATGGCTATGAAGGCATTGTCG & TGGCACATTGGGGTCGATTG & NM_001285 \\
\hline SCGB1A1 & Secretoglobin family $1 \mathrm{~A}$ member 1 & ACATGAGGGAGGCAGGGGCTC & ACTCAAAGCATGGCAGCGGCA & NM_003357 \\
\hline FOXJ1 & Forkhead box protein J1 & GGAGGGGACGTAAATCCCTA & TTGGTCCCAGTAGTTCCAGC & NM_001454 \\
\hline
\end{tabular}

* Used as a reference gene, selected using the Genorm method.

qPCR, quantitative PCR.

panded in T75 culture flasks, pre-coated with a mixture of $30 \mu \mathrm{g} /$ mL Purecol (Advanced BioMatrix, San Diego, CA, USA), $5 \mu \mathrm{g} / \mathrm{mL}$ stabilized fibronectin (Alfa Aesar, Thermo Fisher scientific, Landsmeer, The Netherlands) and $10 \mu \mathrm{g} / \mathrm{mL}$ BSA (Sigma Aldrich, Zwijndrecht, The Netherlands). Next, cells were seeded at a density of 5,000 cells per well for submerged cultures of (S)-PBEC or 40,000 cells per insert (passage 2) on pre-coated 24-well plates (Corning Costar, Cambridge, MA, USA) and semi-permeable Transwell inserts, respectively ( $12 \mathrm{~mm}, 0.4 \mu \mathrm{m}$ pore-size, Corning Costar). The cells were cultured in BEpiCM-b:DMEM (B/D)-medium (1:1; ScienCell Research Laboratories, Uden, The Netherlands and STEMCELL Technologies, Köln, Germany, respectively), supplemented with Bronchial Epithelial Cell Growth Supplement (ScienCell Research Laboratories), and additional 1 nM EC-23 (Tocris, Biotechne Ltd, Abington, UK; for the submerged phase of PBEC cultures on inserts only), 25 mM HEPES (Cayman Chemical, Hamburg, Germany), $100 \mathrm{U} / \mathrm{mL}$ penicillin and $100 \mu \mathrm{g} / \mathrm{mL}$ streptomycin (ScienCell Research Laboratories). After the cells growing on inserts had reached confluence (after 5-7 days), apical medium was removed and the cells were cultured at the air-liquid interface (ALI); the medium was changed 3 times a week with (B/D)-medium supplemented with Bronchial Epithelial Cell Growth Supplement and additional $50 \mathrm{nM}$ EC-23. During refreshment, the apical surface was washed with PBS to remove mucus. After 14 days of air-exposed culture, the cells produced mucus and developed cilia, and cultures were used for experiments. S-PBEC were cultured until they reached 50-70\% confluence after 4-5 days and subsequently cultured for $24 \mathrm{~h}$ in B/D-medium supplemented with Bronchial Epithelial Cell Growth Supplement without BSA, BPE, EGF and hydrocortisone before stimulation (B/D-starvation medium).

\section{Experimental Design}

PBEC that had been differentiated for 14 days at the ALI were exposed to various concentrations of TGF- $\beta 1(0.2,1$ and $5 \mathrm{ng} / \mathrm{mL})$ and $100 \mathrm{nM} 25(\mathrm{OH}) \mathrm{D}_{3}$ and/or $1,25(\mathrm{OH})_{2} \mathrm{D}_{3}$ (Millipore B.V., Amsterdam, The Netherlands) for $24 \mathrm{~h}$ to assess changes in gene ex- pression, or for $48 \mathrm{~h}$ to assess SLPI levels in apical washes, airway epithelial antibacterial activity, and hCAP18/LL-37 release by Western blot or immunofluorescence. S-PBEC cultures were used to elucidate the mechanism of action of TGF- $\beta 1$-reduced expression of hCAP18/LL-37. To assess the role of TGF- $\beta 1$-mediated induction of CYP24A1 or canonical TGF- $\beta 1-S m a d$ signaling, SPBEC were treated with $5 \mathrm{ng} / \mathrm{mL}$ TGF- $\beta 1$ and $100 \mathrm{nM} 1,25(\mathrm{OH})_{2} \mathrm{D}_{3}$ in the presence or absence of $10 \mu \mathrm{M}$ TGF- $\beta 1$-Smad signaling inhibitor SB431542 (Sigma-Aldrich) or $10 \mu \mathrm{M}$ of the antifungal ketoconazole (KTZ) that acts as an inhibitor of CYP-450 (SigmaAldrich) for $24 \mathrm{~h}$.

\section{Silencing of CCAAT/Enhancer-Binding Protein- $\alpha$}

Using siRNA Transfection

S-PBEC were used to determine if the TGF- $\beta 1$-reduced expression of hCAP18/LL-37 was mediated by the transcription factor CCAAT/enhancer-binding protein- $\alpha$. S-PBEC were refreshed with $\mathrm{B} / \mathrm{D}$-starvation medium containing $5 \mathrm{ng} / \mathrm{mL}$ TGF- $\beta 1$ and 100 $\mathrm{nM} 1,25(\mathrm{OH})_{2} \mathrm{D}_{3}$ and transfected using $3 \mu \mathrm{L} /$ well RNAiMAX SilentFect transfection reagent (Thermo Fisher scientific) containing $20 \mathrm{mM} \mathrm{CEBP \alpha}(C E B P A)$ - or negative control (CNTRL)-siRNA (Ambion, Thermo Fisher scientific) and incubated for $24 \mathrm{~h}$.

RNA Isolation, Reverse Transcription and Quantitative PCR

Cells were lysed in RNA lysis buffer (Promega Benelux B.V., Leiden, The Netherlands). The total RNA was robotically extracted using the Maxwell tissue RNA extraction kit (Promega) and quantified using the Nanodrop ND-1000 UV-Vis Spectrophotometer (Nanodrop technologies, Wilmington, DE, USA). For cDNA synthesis, $1 \mu \mathrm{g}$ of total RNA was reverse transcribed using oligo dT primers (Qiagen Benelux B.V., Venlo, The Netherlands) and MMLV Polymerase (Thermo Fisher scientific) at $42^{\circ} \mathrm{C}$. All quantitative PCR (qPCR) reactions were performed in triplicate on a CFX384 Real-Time PCR detection system (Bio-Rad Laboratories, Veenendaal, The Netherlands), using primers shown in Table 1 and IQ SYBRGreen supermix (Bio-Rad). The relative standard curve 
Table 2. Antibodies used for immunofluorescence staining

\begin{tabular}{lllll}
\hline Antibody & Supplier & Catalog number & Species & Antibody dilution \\
\hline CYP24A1 & Sigma & HPA022261 & Rabbit & $1 / 100$ \\
pIgR & R\&D systems & MAB27171 & Mouse & $1 / 50$ \\
P63 & Abcam & ab124762 & Rabbit & $1 / 100$ \\
P63 & Leica & NCL-P63 & Mouse & $1 / 100$ \\
sPLUNC & Hycult biotech & HM2314 & Mouse & $1 / 100$ \\
SLPI & Hycult biotech & HM2037 & Mouse & $1 / 100$ \\
Mucin 5AC & Labvision neomarkers & MS-145-P1 & Mouse & $1 / 1,000$ \\
CC16 & Hycult biotech & HM2178 & Mouse & $1 / 50$ \\
\hline
\end{tabular}

pIgR, polymeric immunoglobulin receptor; SLPI, secretory leukocyte protease inhibitor.

method was used to calculate arbitrary gene expression using CFXmanager software (Bio-Rad). Two reference genes, selected using the "Genorm method" (Genorm, Primer design, Southampton, $\mathrm{UK})$, were included to calculate the normalized gene expression.

\section{Western Blot}

For Western blot analysis of hCAP18/LL-37 release, basal medium was applied to Oasis HLB 1cc extraction cartridges (Waters Chromatography, Etten-Leur, The Netherlands) and the eluate was dried by vacuum centrifugation (CHRIST RVC2-25 Vacuüm system) [41]. Lyophilized protein samples were resuspended in $100 \mu \mathrm{L}$ reducing SDS-PAGE sample buffer, heated for $5 \mathrm{~min}$ at $100{ }^{\circ} \mathrm{C}$ and applied on a $16.5 \%$ Tris-Tricine gel, as previously described [5]. Next, proteins were blotted on a Polyvinylidene fluoride membrane and non-specific binding sites were blocked in PBS containing $5 \%(\mathrm{v} / \mathrm{v})$ heat-inactivated new born calf serum, 5\% $(\mathrm{w} / \mathrm{v})$ skimmed milk in PBS. Membranes were probed with $1 / 200$ diluted mouse monoclonal anti-hCAP18/LL-37 (clone 1.1.C12; Hycult Biotech, Uden, The Netherlands) in blocking buffer. Next, the membranes were incubated in 1/1,000 diluted rabbit-antimouse-HRP (Cell Signaling Technology, Leiden, The Netherlands) in blocking buffer. SuperSignal West Pico ECL Substrate (Thermo Fisher scientific) was used to visualize hCAP18/LL-37 protein using The ChemiDoc ${ }^{\mathrm{TM}}$ Touch imager in combination with Image $\mathrm{Lab}^{\mathrm{TM}}$ software (Biorad).

\section{Immunofluorescence Staining of CYP24A1, SLPI, sPLUNC and pIgR}

Cells were fixed on Transwell inserts in 1\% paraformaldehyde (Millipore B.V.) in PBS for 10 min on ice and washed with ice-cold PBS. Next, cells were permeabilized with methanol for $10 \mathrm{~min}$ at $4{ }^{\circ} \mathrm{C}$, washed in PBS, and blocked with $\mathrm{PBS} / 1 \%$ (w/v) BSA $/ 0.3 \%$ (v/v) Triton-X-100 (PBT) for $30 \mathrm{~min}$ at $4^{\circ} \mathrm{C}$. Next, cells were treated for 30 min with SFX-signal enhancer (Thermo Fisher scientific) followed by incubation with primary antibodies in PBT for $1 \mathrm{~h}$ at reverse transcription (RT; Table 2). After washing in PBS, cells were incubated with an Alexa Fluor 488 labeled secondary antibody (1/200, Alexa Fluor 488 goat anti-rabbit IgG; Thermo Fisher scientific) and Alexa Fluor 568 goat anti-mouse IgG together with DAPI (Sigma Aldrich) in PBT for $30 \mathrm{~min}$ at RT in the dark. Finally, cells were mounted in ProLong ${ }^{\mathrm{TM}}$ Gold Antifade Mountant (Thermo Fisher scientific) and images were acquired using a TCS
SP5 Confocal Laser Scanning Microscope (Leica Microsystems B.V., Eindhoven, The Netherlands) and LAS AF Lite software (Leica Microsystems B.V.).

\section{SLPI ELISA}

Apical washes were obtained by washing the apical surface of the stimulated ALI-PBEC with $200 \mu \mathrm{L}$ warm PBS for $10 \mathrm{~min}$ at $37^{\circ} \mathrm{C}$. SLPI in apical washes of the treated ALI-PBEC was measured using an ELISA, as previously described [42].

\section{Antibacterial Activity Assay}

Antibacterial activity was assessed by applying log-growing cultures of NTHi on the apical surface of the treated cells, as previously described, with a few modifications [40]. NTHi strain D1 was cultured in Tryptone soya broth containing X and V-factor (TSB XV, Mediaproducts BV, Groningen, the Netherlands) while shaking overnight at $37^{\circ} \mathrm{C} \mathrm{[2].} \mathrm{Next,} 2 \mathrm{~mL}$ of the overnight culture was transferred into fresh $10 \mathrm{~mL}$ TSB XV medium and incubated for $4 \mathrm{~h}$ at $37^{\circ} \mathrm{C}$ while shaking to obtain mid log phase growing bacteria. Before applying the washed bacterial suspensions to the apical surface of ALI-PBEC, excess mucus was removed by washing both treated and untreated cells with $200 \mu \mathrm{L} 10 \mathrm{mM}$ sodium phosphate buffer for $15 \mathrm{~min}$ at $37^{\circ} \mathrm{C} 6 \mathrm{~h}$ before the assay. We applied approximately 1 multiplicity of infection NTHi in $20 \mu \mathrm{L}$ sodium phosphate buffer $+1 \% \mathrm{v} / \mathrm{v}$ TSB XV per insert for $2 \mathrm{~h}$. Next, membranes containing the cells with bacteria were dissected from the inserts and placed into tubes containing sterile glass beads and 1\% TSB in PBS, and cells were disrupted by using a Minilys personal homogenizer (Bertin Instruments, Montigny-le-Bretonneux, France) for 2 times $30 \mathrm{~s}$ and kept on ice between treatments. Serial dilutions of bacterial suspensions were plated on chocolate agar plates (Biomerieux, Zaltbommel, The Netherlands), and incubated overnight at $37^{\circ} \mathrm{C}$ to assess surviving bacteria by colony forming unit determination.

\section{Statistical Analysis}

Statistical analysis was conducted using GraphPad Prism 7 (GraphPad Software Inc., La Jolla, CA, USA). To analyze the qPCR results, fold change in gene expression of the stimuli compared to CNTRL was first calculated, followed by log-transformation. All data were analyzed using a two-way ANOVA and the Bonferroni post-hoc test. Differences at $p$ values $<0.05$ were considered statistically significant. 

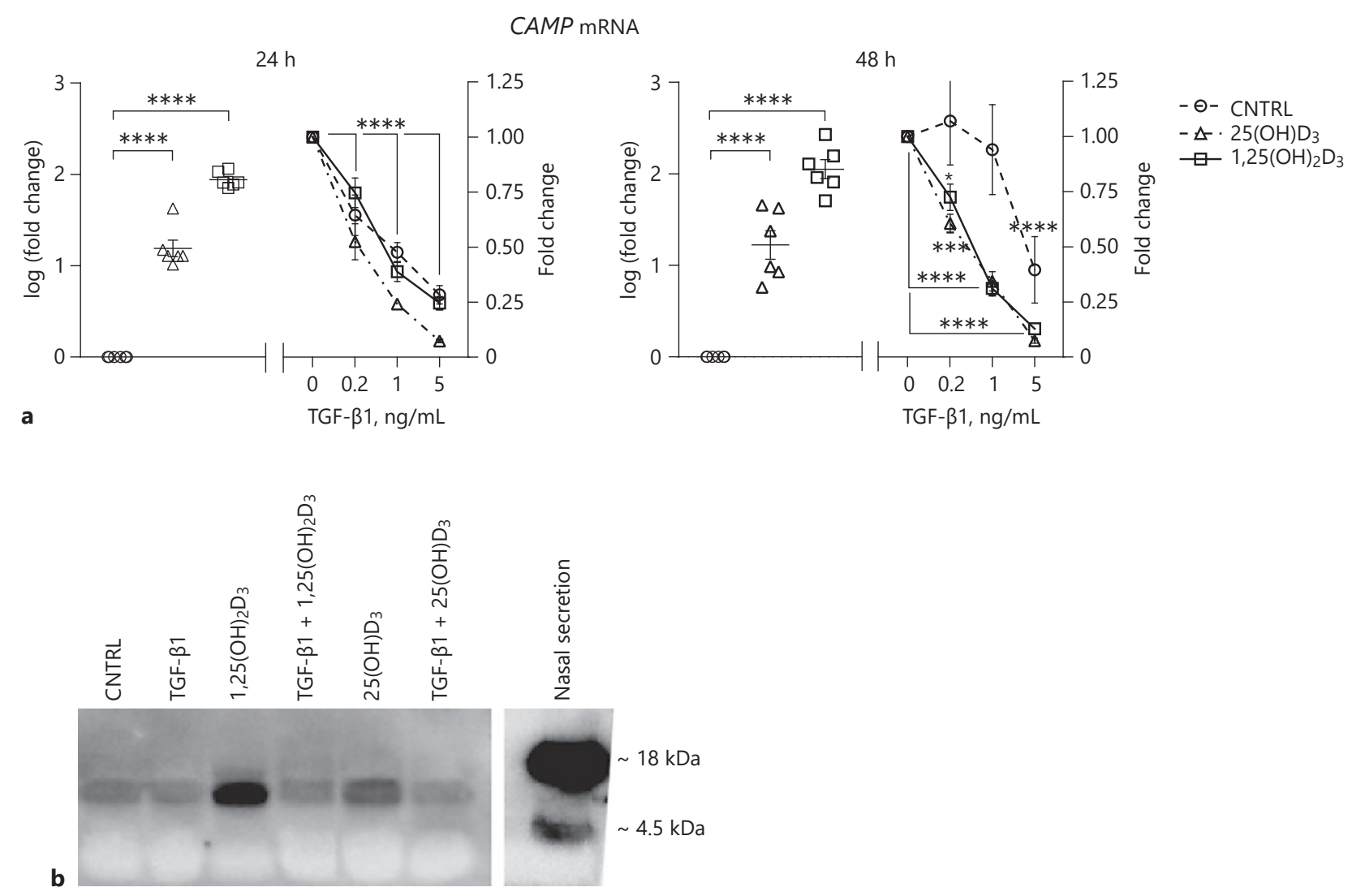

Fig. 1. TGF- $\beta 1$ impairs baseline and vitamin $D$-induced expression and release of hCAP18/LL-37 in PBEC. PBEC were differentiated at the ALI followed by $24-48 \mathrm{~h}$ stimulation with TGF- $\beta 1$ with or without inactive $25(\mathrm{OH}) \mathrm{D}_{3}$, active $1,25(\mathrm{OH})_{2} \mathrm{D}_{3}$ or medium CNTRL to determine the mRNA expression of CAMP (hCAP18/ LL-37) by qPCR (a), and cells were stimulated for $48 \mathrm{~h}$ to assess the release of hCAP18/LL-37 by Western blot analysis (b). a Relative mRNA expression of CAMP was determined by qPCR. Normalized gene expression was calculated by using the expression of YWHAZ and RPL27 as reference genes. Fold change in the gene expression of $25(\mathrm{OH}) \mathrm{D}_{3}$ and $1,25(\mathrm{OH})_{2} \mathrm{D}_{3}$ compared to CNTRL was first calculated, followed by a log-transformation of the data. To assess the effects of different doses of TGF- $\beta 1$ on CAMP expres-

\section{Results}

TGF- $\beta 1$ Impairs Baseline and VD-Induced Expression and Release of hCAP18/LL-37 in Differentiated PBECs

We have previously shown that exposure to pro-inflammatory stimuli impairs VD-induced expression and release of the HDP hCAP18/LL-37 in differentiated ALIPBEC [43]. To investigate if TGF- $\beta 1$ also affects the expression of the VD-responsive HDP hCAP18/LL-37 sion in $25(\mathrm{OH}) \mathrm{D}_{3}, 1,25(\mathrm{OH})_{2} \mathrm{D}_{3}$ and CNTRL-treated cells, fold change for each group was calculated separately. Data are presented as individual values, including means \pm SEM and tested for significance using the two-way ANOVA and the Bonferroni post-hoc test ( $n=6$ donors). b Tris-Tricine gel electrophoresis, followed by Western blot analysis was used to detect hCAP18/LL-37 production in basal medium. Nasal secretion was used as positive CNTRL to show both intact hCAP18 peptide and cleaved mature LL-37 peptide at 18 and $4.5 \mathrm{kDa}$, respectively. Western blots are representative of 4 different donors. The image was cut to include the image of nasal secretion. ${ }^{* * *} p<0.001,{ }^{* * * *} p<0.0001$. RPL27, ribosomal protein L2; YWHAZ, tyrosine 3-monooxygenase/tryptophan 5-monooxygenase activation protein zeta.

$(C A M P)$, we exposed differentiated ALI-PBEC to various concentrations of TGF- $\beta 1$ for $24-48 \mathrm{~h}$ in the presence and absence of $25(\mathrm{OH}) \mathrm{D}_{3}$ (this inactive form of VD is converted in PBEC by CYP27B1 into active $\left.1,25[\mathrm{OH}]_{2} \mathrm{D}_{3}\right)$ ). We first confirmed that both $25(\mathrm{OH}) \mathrm{D}_{3}$ and $1,25(\mathrm{OH})_{2} \mathrm{D}_{3}$ clearly increased the expression of CAMP mRNA in ALIPBEC after $24-48 \mathrm{~h}$ of incubation (Fig. 1a). TGF- $\beta 1$ dosedependently limited the VD-increased expression of $C A M P$ at both time points, whereas all concentrations of 
TGF- $\beta 1$ decreased the baseline expression of CAMP after $24 \mathrm{~h}$ and - only at the highest dose - after $48 \mathrm{~h}$ (Fig. 1a). To verify TGF- $\beta 1$-mediated repression of CAMP at the protein level, we exposed ALI-PBEC to the highest dose TGF- $\beta 1(5 \mathrm{ng} / \mathrm{mL})$ in the presence and absence of $25(\mathrm{OH})$ $\mathrm{D}_{3}$ and/or $1,25(\mathrm{OH})_{2} \mathrm{D}_{3}$ for $48 \mathrm{~h}$, and assessed hCAP18/ LL-37 secretion in basal medium using Western blot analysis. Using Western blot analysis, both $1,25(\mathrm{OH})_{2} \mathrm{D}_{3}$ and $25(\mathrm{OH}) \mathrm{D}_{3}$ clearly increased the release of hCAP18/ LL-37 in basal medium, which was reduced by TGF- $\beta 1$, in line with gene expression data (Fig. 1b). These data demonstrate that TGF- $\beta 1$ interferes with baseline and VD-mediated signaling, resulting in reduced expression and release of the HDP hCAP18/LL-37.

\section{TGF- $\beta 1$ Affects the VD-Metabolic Pathway}

To investigate if the effects of TGF- $\beta 1$ on VD-mediated expression of hCAP18/LL-37 were mediated by changes in the VD-metabolic pathway, we assessed the effects of TGF- $\beta 1$ on the expression of the VD-degrading enzyme CYP24A1, the VD-activating enzyme CYP27B1, and the VDR. ALI-PBEC were exposed to various concentrations of TGF- $\beta 1$ for $24-48 \mathrm{~h}$ in the presence and absence of $25(\mathrm{OH}) \mathrm{D}_{3}$ and $1,25(\mathrm{OH})_{2} \mathrm{D}_{3}$. As expected, both forms of VD increased the CYP24A1 expression (Fig. 2a, left side) compared to CNTRL treated cells. In the absence of VD, TGF- $\beta 1$ markedly increased the CYP24A 1 expression, and even caused a further small increase in the presence of both forms of VD (Fig. 2a). Furthermore, we also observed a minor dose-dependent change in $V D R$ expression and no effect of TGF- $\beta 1$ on the expression of CYP27B1 (Fig. 2a). To verify these effects of TGF- $\beta 1$ on CYP24A1 at the protein level, we performed immunofluorescence staining using CYP24A1 antibodies and confirmed the ability of TGF- $\beta 1$ to increase the CYP24A1 expression at the protein level in the presence and absence of $1,25(\mathrm{OH})_{2} \mathrm{D}_{3}$ (Fig. 2b). Together these data indicate that TGF- $\beta 1$ affects VD metabolism by increasing the expression of the VD-degrading enzyme CYP24A1.

\section{Effects of Inhibition of CYP24A1 Activity and}

Canonical TGF- $\beta$-Smad Signaling on the Expression

of $h$ CAP18/LL-37 (CAMP) and CYP24A1

We used S-PBEC to further elucidate the underlying mechanisms of TGF- $\beta 1$-mediated decreases of hCAP18/ LL-37 and increases of CYP24A1 (Fig. 3a, b), after observing that modulation of CAMP and CYP24A1 expression by TGF- $\beta 1$ was similar in S-PBEC and ALI-PBEC (data not shown). We first investigated if the TGF- $\beta 1$-mediated repression of VD-induced hCAP18/LL-37 was fully mediated by increases of CYP24A1 expression. To this end, S-PBEC were exposed for $24 \mathrm{~h}$ to TGF- $\beta 1$ and $1,25(\mathrm{OH})_{2} \mathrm{D}_{3}$ in the presence or absence of the CYP-inhibitor KTZ that is known to inhibit CYP24A1 and CYP27B1 activity [44, 45]. To circumvent the effect of KTZ-mediated inhibition of the CYP27B1-mediated hydroxylation of inactive $25(\mathrm{OH}) \mathrm{D}_{3}$ into active $1,25(\mathrm{OH})_{2} \mathrm{D}_{3}$, we used only $1,25(\mathrm{OH})_{2} \mathrm{D}_{3}$ in these experiments. Whereas KTZ significantly increased $1,25(\mathrm{OH})_{2} \mathrm{D}_{3}$-mediated expression of $C A M P$ in both the presence and absence of TGF- $\beta 1$, $C A M P$ levels were lower in $1,25(\mathrm{OH})_{2} \mathrm{D}_{3}$-treated cells in the presence of TGF- $\beta 1$ than in the absence of TGF- $\beta 1$ (Fig. 3a). This suggests that the VD-mediated reduction of $C A M P$ by TGF- $\beta 1$ was not fully explained by increased CYP24A1, suggesting involvement of mechanisms other than the VD-metabolic pathway in the observed effects of TGF- $\beta 1$.

In addition to VD-mediated expression of $C A M P$, the baseline expression of $C A M P$ was also reduced by TGF- $\beta 1$ and this could not be restored by inhibition of CYP24A1 (Fig. 3a). TGF- $\beta 1$ signals through either the canonicalSmad signaling pathway or the non-canonical (MAPK/ NF- $\kappa B$ )-pathway [46]. To investigate if the canonical TGF- $\beta$-Smad signaling pathway was involved in the inhibition of baseline $C A M P$ expression as well as the increase in CYP24A1, we exposed S-PBEC to TGF- $\beta 1$ and $1,25(\mathrm{OH})_{2} \mathrm{D}_{3}$ in the presence or absence of SB431542 (an inhibitor of TGF- $\beta$ type I receptor activin receptor-like kinase and further downstream signaling, that is, via receptor regulated (R)-Smads) [46]. We found that treatment with SB431542 fully reversed the effects of TGF- $\beta 1$ on both CAMP and CYP24A1 expression, both in the absence or in the presence of $1,25(\mathrm{OH})_{2} \mathrm{D}_{3}$ (Fig. 3b). These results indicate that the canonical TGF- $\beta$-Smad signaling pathway mediates the reduction of CAMP and the promotion of CYP24A1 expression by TGF- $\beta 1$.

\section{TGF- $\beta 1$ Decreases Expression of CAMP via the}

Transcription Factor CCAAT Enhancer Binding Protein $(C / E B P) \alpha$

In addition to VD-responsive elements that bind the VDR-RXR-1,25(OH $)_{2} \mathrm{D}_{3}$-complex, the promotor of $C A M P$ also contains a binding site for the transcription factor $\mathrm{C} / \mathrm{EBP} \alpha$, which was shown to be required for the induction of CAMP independent of VD [47]. A study by Li et al. [48] showed that TGF- $\beta$-Smad signaling inhibits the expression of $\mathrm{C} / \mathrm{EBP} \alpha \mathrm{mRNA}$ in mesenchymal stem cells, which suggests the involvement of $\mathrm{C} / \mathrm{EBP} \alpha$ in the suppressive effect of TGF- $\beta 1$ on CAMP expression. We 


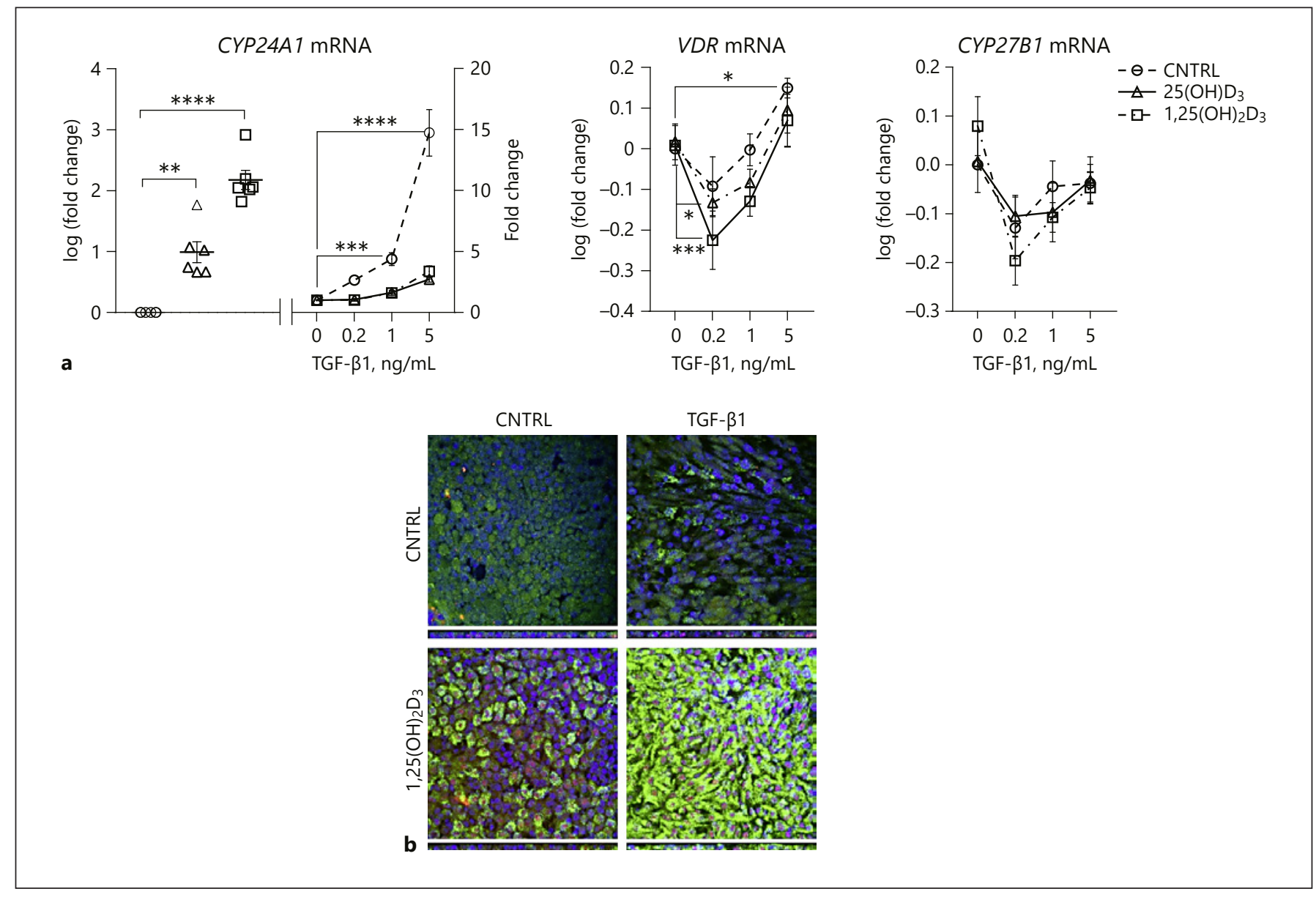

Fig. 2. TGF- $\beta 1$ affects the vitamin D-metabolic pathway in PBEC. PBEC were differentiated at the ALI followed by $24 \mathrm{~h}$ stimulation with TGF- $\beta 1$ in the presence or absence of $25(\mathrm{OH}) \mathrm{D}_{3}, 1,25(\mathrm{OH})_{2} \mathrm{D}_{3}$ or medium CNTRL to assess the mRNA expression of the VDdegrading enzyme (CYP24A1), VDR and the VD-activating enzyme (CYP27B1) by qPCR (a). In addition, cells were stimulated with TGF- $\beta 1$ with or without $1,25(\mathrm{OH})_{2} \mathrm{D}_{3}$ or medium CNTRL for $48 \mathrm{~h}$ to assess the expression of CYP24A 1 by immunofluorescence (b). a Relative mRNA expression of CYP24A1, VDR, and CYP27B1 was determined by qPCR. Normalized gene expression was calculated by using the expression of YWHAZ and RPL27 as reference genes. To determine the effects of $25(\mathrm{OH}) \mathrm{D}_{3}$ and $1,25(\mathrm{OH})_{2} \mathrm{D}_{3}$ on CYP24A1 expression, fold change in gene expression was first calculated, followed by a log-transformation of the data. Furthermore,

first demonstrated that TGF- $\beta 1$ also reduced the mRNA CEBPA expression in S-PBEC after $24 \mathrm{~h}$ (Fig. 4a). To investigate the involvement of $\mathrm{C} / \mathrm{EBP} \alpha$ in baseline and $\mathrm{VD}$ induced CAMP expression, we used siRNA. S-PBEC were transfected with CEBPA-specific siRNA or negative CNTRL siRNA and next cells were exposed to TGF- $\beta 1$ and $1,25(\mathrm{OH})_{2} \mathrm{D}_{3}$ for $24 \mathrm{~h}$. siRNA caused a marked suppression of CEBPA expression, and both basal- and effects of different doses of TGF- $\beta 1$ on CYP24A1, VDR, and CYP27B1 expression were determined by calculating the fold change relative to the corresponding CNTRL without TGF- $\beta 1$ (CNTRL, $25[\mathrm{OH}] \mathrm{D}_{3}$ or $1,25[\mathrm{OH}]_{2} \mathrm{D}_{3}$ ). Data are presented as individual values, including means \pm SEM and were tested for significance using the two-way ANOVA and the Bonferroni post-hoc test ( $n=6$ donors). b Cells were stimulated for $48 \mathrm{~h}$ to assess the expression of CYP24A1 and basal cells (P63) by confocal immunofluorescence staining (data of 1 donor are shown, similar findings were observed in 3 other donors). DAPI (blue) was used to stain the nuclei together with antibodies detecting CYP24A1 (green) and P63 (red). ${ }^{*} p<0.05,{ }^{* *} p<0.01,{ }^{* * *} p<0.001,{ }^{* * * *} p<0.0001 . R P L 27$, ribosomal protein L27; YWHAZ, tyrosine 3-monooxygenase/ tryptophan 5-monooxygenase activation protein zeta.

$1,25(\mathrm{OH})_{2} \mathrm{D}_{3}$-mediated expression of $C A M P$ was reduced (Fig. 4b). The siRNA-induced reductions in both $C E B P A$ and $C A M P$ expression were more pronounced in TGF- $\beta 1$-treated cells (Fig. 4b). We next measured the expression of CYP24A1, to exclude possible non-specific effects of CEBPA siRNA transfection. Unexpectedly, CYP24A1, a gene without any known binding sides for C/ $\mathrm{EBP} \alpha$ in its promotor, was also decreased (Fig. 4b). Since
80

J Innate Immun 2020;12:74-89 DOI: $10.1159 / 000497415$
Schrumpf/Ninaber/van der Does/ Hiemstra 


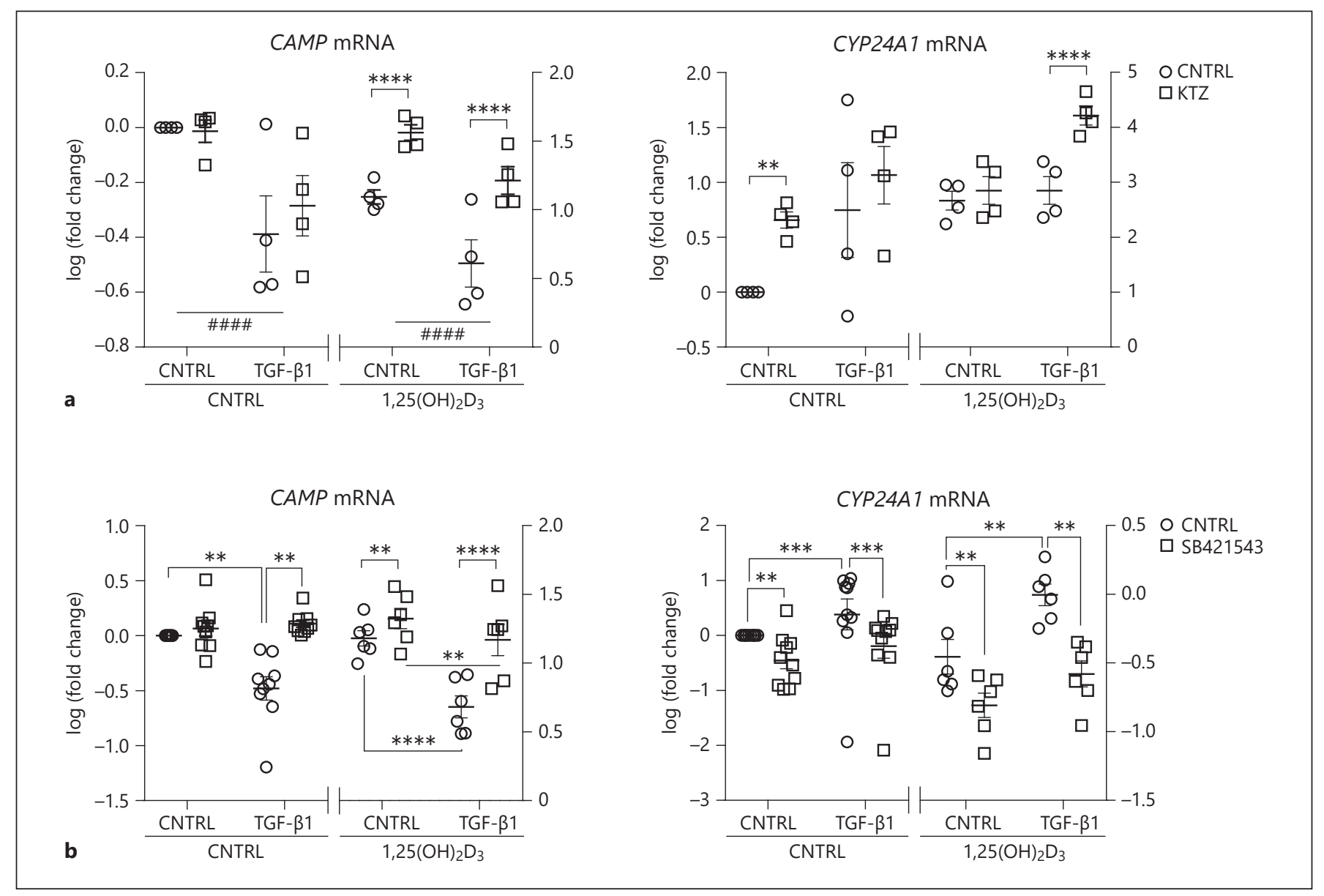

Fig. 3. Effects of inhibition of CYP24A1 activity and canonical TGF- $\beta$-Smad signaling on expression of hCAP18/LL-37 (CAMP) and CYP24A1 in PBEC. Semi-confluent layers of submerged (S)PBEC were cultured in starvation medium overnight and subsequently exposed to the CYP-450-inhibitor KTZ (a) or to the canonical TGF- $\beta$-Smad signaling-inhibitor SB421543 (b) in the presence or absence of TGF- $\beta 1$ and $1,25(\mathrm{OH})_{2} \mathrm{D}_{3}$, or medium CNTRL for $24 \mathrm{~h}$ to assess the mRNA expression of CAMP (hCAP18/LL-37) and the vitamin D-degrading enzyme (CYP24A1) by qPCR. Relative mRNA expression of CAMP and CYP24A1 was determined by qPCR. Normalized gene expression

Fig. 4. TGF- $\beta 1$ decreases the expression of the CAMP-transcription factor CCAAT enhancer binding protein (C/EBP) $\alpha$ in PBECs. Semi-confluent cultures of submerged (S)-PBEC were cultured in starvation medium overnight and subsequently exposed to TGF- $\beta 1$ or medium CNTRL for $24 \mathrm{~h}$ to assess the mRNA expression of C/ $\mathrm{EBP}) \alpha(C E B P A)$ by qPCR (a). PBEC were refreshed with starvation medium containing medium alone (CNTRL) or TGF- $\beta 1$ with and without $1,25(\mathrm{OH})_{2} \mathrm{D}_{3}$ and subsequently transfected with CEBPA siRNA for $24 \mathrm{~h}$. Scrambled siRNA was used as a CNTRL (siRNA). mRNA expression of CEBPA, CAMP (hCAP18/LL-37), the VDdegrading enzyme $(C Y P 24 A 1)$ and $C / E B P) \beta(C E B P B)$ was assessed was calculated by using the expression of YWHAZ and RPL27 as reference genes. To determine the effects of the stimuli, fold change in gene expression compared to CNTRL was first calculated, followed by a log-transformation of the data. Data are presented as individual values, including means \pm SEM and were tested for significance using the two-way ANOVA and the Bonferroni post-hoc test (a, $n=4$ donors; $\mathbf{b}, n=6-10$ donors). ${ }^{* *} p<$

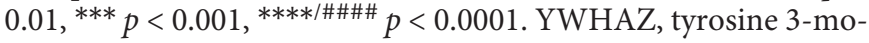
nooxygenase/tryptophan 5-monooxygenase activation protein zeta; RPL27, ribosomal protein L27.

by qPCR (b). Relative mRNA expression was determined by qPCR. Normalized gene expression was calculated by using the expression of YWHAZ and RPL27 as reference genes. To determine the effects of the stimuli, fold change in gene expression compared to CNTRL was first calculated, followed by a log-transformation of the data. Data are presented as individual values, including means \pm SEM and were tested for significance using the two-way ANOVA and the Bonferroni post-hoc test ( $\mathbf{a}, n=10$ donors; $\mathbf{b}, n=4$ donors).

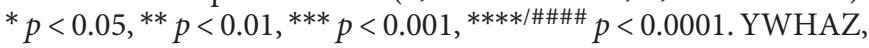
tyrosine 3-monooxygenase/tryptophan 5-monooxygenase activation protein zeta; RPL27, ribosomal protein L27.

(For figure see next page.) 
the CYP24A1-promotor does contain binding sides for $\mathrm{C} / \mathrm{EBP} \beta(C E B P B)$ [49], we considered the possibility that $C E B P A$ siRNA also had reduced $C E B P B$ mRNA levels. We therefore assessed the expression of $C E B P B$ and found that this was not affected, suggesting that inhibi- tion of $\mathrm{C} / \mathrm{EBP} \alpha$ might have indirectly affected the expression of CYP24A1 (Fig. 4b). Collectively, these data show that TGF- $\beta 1$-mediated changes in CAMP or CYP $24 A 1$ expression are mediated through repression of the transcription factor (C/EBP) $\alpha$ by TGF- $\beta 1$.

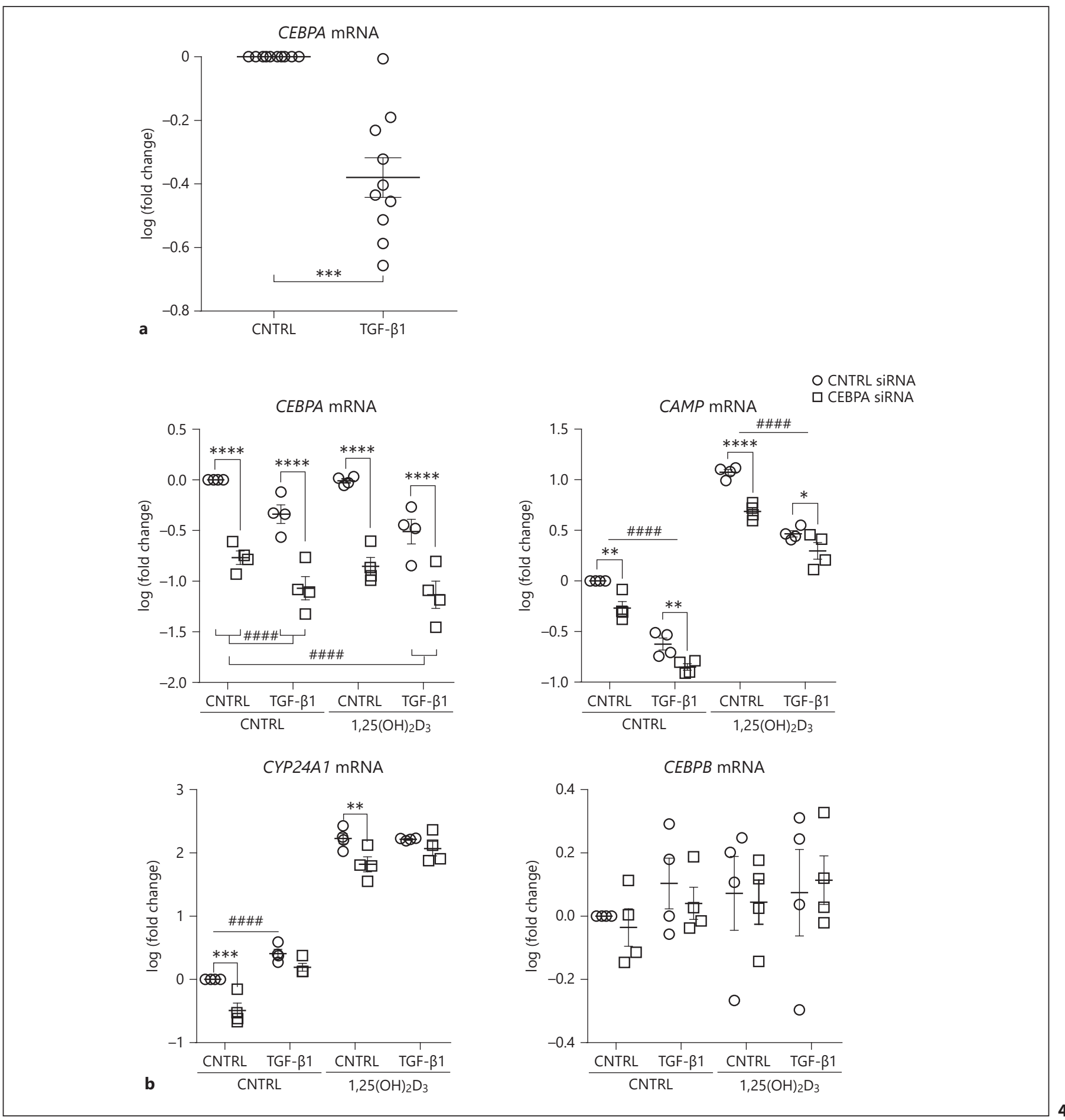




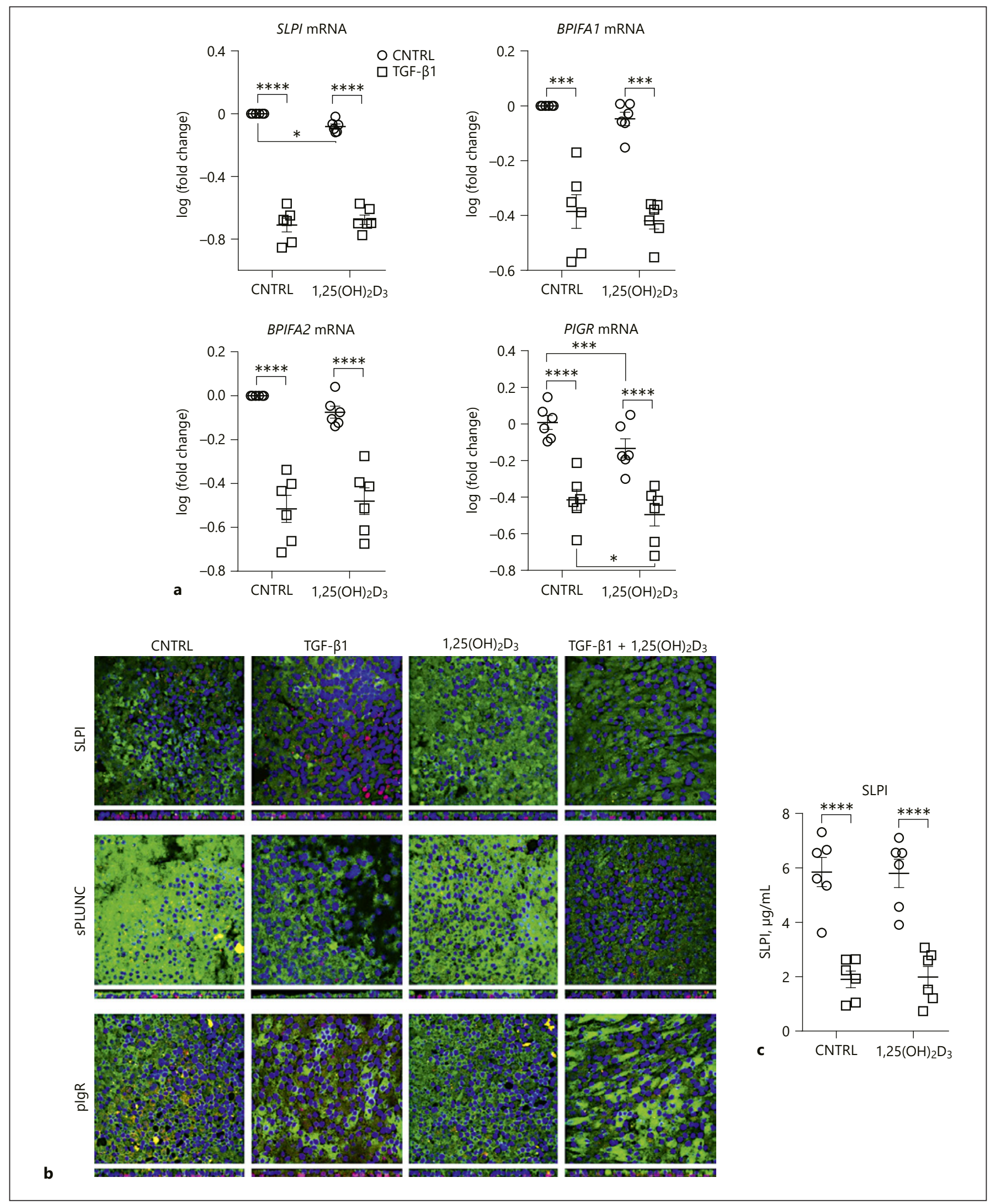

(For legend see next page.)

Modulation of Airway Host Defence Responses by TGF- $\beta 1$ and VD
J Innate Immun 2020;12:74-89 DOI: $10.1159 / 000497415$ 
Effect of TGF- $\beta 1$ on the Expression of Constitutively

Expressed Luminal Cell-Restricted Host Defense

\section{Mediators}

Since we demonstrated reduced expression levels of the inducible HDP hCAP18/LL-37 in the presence of VD and TGF- $\beta 1$, we were interested in investigating whether a similar decrease was also observed in the expression of constitutively expressed host defense mediators such as the HDP SLPI and pIgR, since previous studies showed that they were repressed by TGF- $\beta 1$ alone in ALI-PBEC $[31,50]$. Investigating effects of the combination of TGF- $\beta 1$ and VD is especially relevant, since VD reduces the effects of TGF- $\beta 1$-mediated EMT in airway epithelial cell lines [35]. We therefore investigated in ALI-PBEC if VD affected the TGF- $\beta 1$-induced repression of a selected group of constitutively expressed host defense mediators such as SLPI, s/lPLUNC and pIgR. To this end, differentiated ALI-PBEC were exposed to both TGF- $\beta 1$ and $1,25(\mathrm{OH})_{2} \mathrm{D}_{3}$ for $24-48 \mathrm{~h}$, and the expression of these mediators was assessed. TGF- $\beta 1$ decreased the expression of all 3 selected HDPs after 24 h (Fig. 5a), which continued up to $48 \mathrm{~h}$ (data not shown). However, $1,25(\mathrm{OH})_{2} \mathrm{D}_{3}$ did not prevent the TGF- $\beta 1$-meditiated repression of mRNA expression of these constitutively expressed HDPs (Fig. 5a). We additionally verified these effects of TGF- $\beta 1$ at the protein level using confocal immunofluorescence, and using ELISA to detect SLPI in apical secretions (Fig. 5b, c). TGF- $\beta 1$-treatment reduced both the staining intensity as well as the number of SLPI- and sPLUNCpositive cells, whereas only the number of pIgR-positive cells was reduced upon TGF- $\beta 1$-treatment. In cultures from some donors, pIgR was relocated from the cell membrane towards the cytoplasm (Fig. 5b).

We furthermore investigated the functional consequences of the reduced expression of the HDPs by

Fig. 5. Effect of TGF- $\beta 1$ on the expression of constitutively expressed luminal cell-restricted host defense proteins (HDPs) in PBECs. PBEC were differentiated at the ALI followed by stimulation for $24 \mathrm{~h}$ with TGF- $\beta 1$ in the presence or absence of $1,25(\mathrm{OH})_{2} \mathrm{D}_{3}$ and medium control (CNTRL) to assess the mRNA expression of $S L P I$, short- and long-Palate, lung, and nasal epithelium clone protein (PLUNC; BPIFA1 and BPIFA2 respectively) and polymeric immunoglobulin receptor (PIGR) by qPCR (a). In addition, cells were stimulated for $48 \mathrm{~h}$ to assess the expression of these HDPs by confocal immunofluorescence (SLPI, sPLUNC and pIgR) and the apical side of the inserts were washed in PBS to assess the release of SLPI by ELISA (b). a Relative mRNA expression of CAMP was determined by qPCR. Normalized gene expression was calculated by using the expression of YWHAZ and RPL27 as reference genes. Fold changes in gene expression of the stimuli compared to
TGF- $\beta 1$ in the presence and absence of VD by studying the effects of TGF- $\beta 1$ and VD on antibacterial activity. Differentiated ALI-PBEC were exposed to TGF- $\beta 1$ for $48 \mathrm{~h}$ in the presence and absence of $1,25(\mathrm{OH})_{2} \mathrm{D}_{3}$ and a killing assay was performed by applying log-growing NTHi on the apical surface of 48 h-exposed cells for $2 \mathrm{~h}$. The cell lysates were next diluted and incubated on agar plates overnight to determine surviving bacteria. In contrast to what was previously observed using a different type of antibacterial assay [5], we found that treatment with $1,25(\mathrm{OH})_{2} \mathrm{D}_{3}$ did not increase the antibacterial activity against NTHi. Although not significant, there was a small trend towards reduction of antibacterial activity by TGF- $\beta 1$ (online suppl. Fig. S1; for all online suppl. material, see www.karger.com/ doi/10.1159/000497415).

\section{TGF- $\beta 1$ Modulates Epithelial Differentiation}

To investigate whether the ability of TGF- $\beta 1$ to reduce the expression and release of the constitutively expressed HDPs SLPI, s/lPLUNC and pIgR was explained by TGF$\beta 1$-induced changes in epithelial differentiation, effects on differentiation markers were assessed. These experiments were prompted by our recent finding that chronic exposure to CS also impairs the expression and release of these HDPs, accompanied by an impairment of end-stage airway epithelial cell differentiation towards club and goblet cells, being the main source of these HDPs [40]. Furthermore, it was shown that TGF- $\beta 1$ directs epithelial cells to dedifferentiate, and we therefore investigated if specialized epithelial cells were reduced by TGF- $\beta 1$ and if VD might counteract this reduction [51]. We therefore exposed differentiated ALI-PBEC to TGF- $\beta 1$ and $1,25(\mathrm{OH})_{2} \mathrm{D}_{3}$ for $24-48 \mathrm{~h}$ and observed that TGF- $\beta 1$ caused a clear reduction in both mRNA expression of the

CNTRL were first calculated, followed by a log-transformation of the data. Data are presented as individual values, including means \pm SEM and were tested for significance using the two-way ANOVA and the Bonferroni post-hoc test ( $n=6$ donors). $\mathbf{b}$ Confocal immunofluorescence staining of HDPs and basal cells in ALI-PBEC (of 1 donor, which was confirmed in 3-5 other donors), DAPI (blue) was used to stain the nuclei and antibodies (Table 2) was used for the detection of HDPs (green) and basal cells (P63, red) respectively. c Analysis of SLPI in apical wash by ELISA. Data are presented as individual values, including mean \pm SEM and were tested for significance using the two-way ANOVA and the Bonferroni post-hoc test ( $n=6$ donors). ${ }^{*} p<0.05,{ }^{* * *} p<0.001,{ }^{* * * *} p<$ 0.0001 . YWHAZ, tyrosine 3-monooxygenase/tryptophan 5-monooxygenase activation protein zeta; RPL27, ribosomal protein L27.
Schrumpf/Ninaber/van der Does/ Hiemstra 


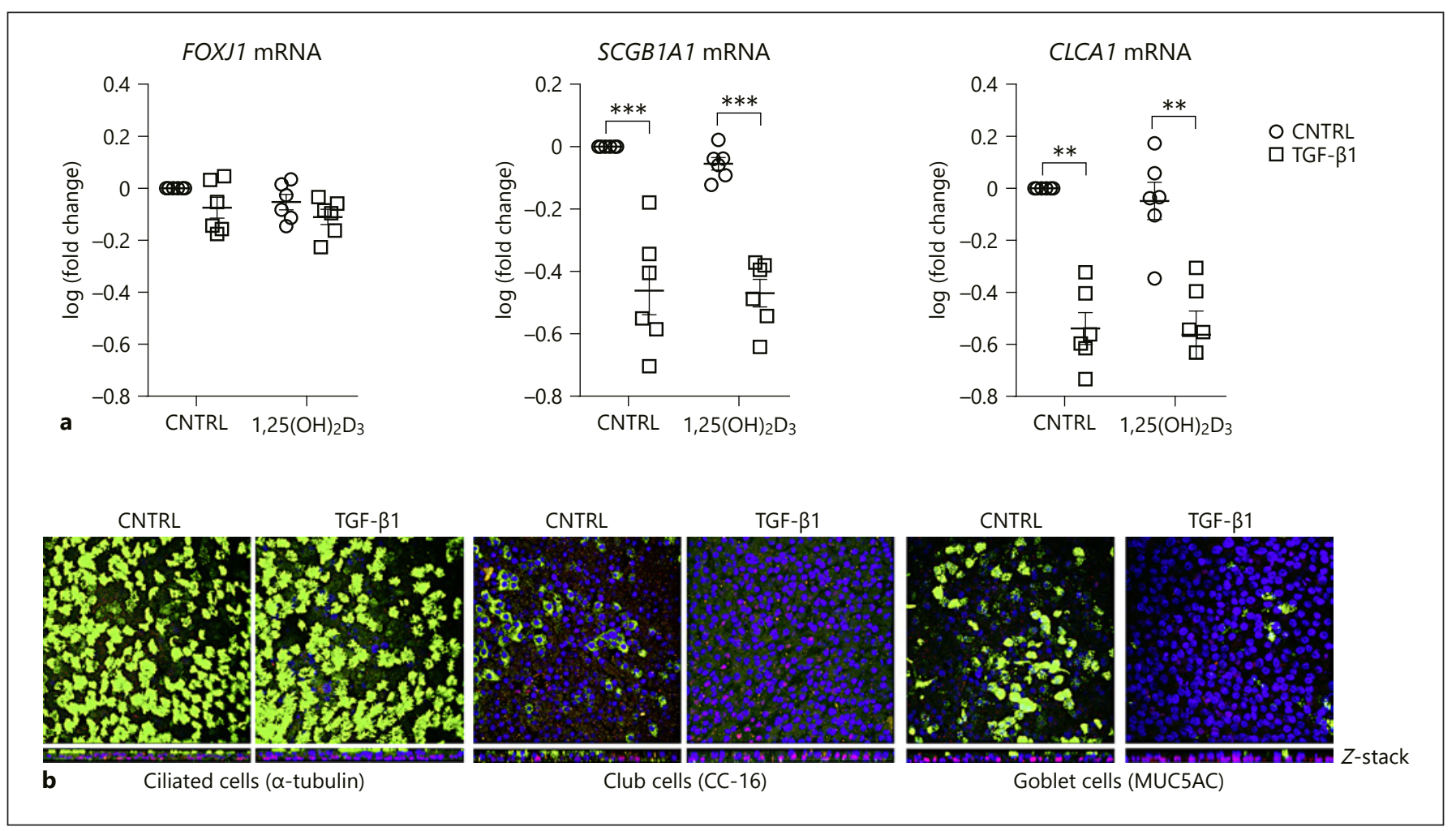

Fig. 6. TGF- $\beta 1$ affects the composition of airway epithelium by decreasing the number of secretory epithelial cells in PBECs. PBEC were differentiated at the ALI followed by stimulation for $24 \mathrm{~h}$ with TGF- $\beta 1$ in the presence or absence of $1,25(\mathrm{OH})_{2} \mathrm{D}_{3}$ or medium alone (CNTRL) to assess the mRNA expression of markers related to ciliogenesis (FOXJ1), club cells (SCGB1A1) and goblet cells (CLCA1) by qPCR (a). In addition, cells were stimulated for $48 \mathrm{~h}$ to assess the numbers of ciliated, club and goblet cells by confocal immunofluorescence (b). a Relative mRNA expression of FOXJ1, SCGB1A1 and CLCA1 was determined by qPCR. Normalized gene expression was calculated by using the expression of YWHAZ and RPL27 as reference genes. Fold changes in gene expression of the

club and goblet cell markers SCGB1A1 and CLCA1, respectively, as well as in the number of CC16 (club cell) and MUC5AC (goblet cell)-positive cells observed by confocal immunofluorescence staining. mRNA expression of the ciliated cell marker (FOXJ1) as well the number of ciliated cells were unaffected by TGF- $\beta 1$ (Fig. $6 \mathrm{a}$, b). $1,25(\mathrm{OH})_{2} \mathrm{D}_{3}$ alone did not affect mRNA or protein expression of these cell markers, and did not prevent the TGF- $\beta 1$-induced decreases in SCGB1A1 and CLCA1 mRNA (Fig. 6a; immunofluorescence data not shown). This indicates that TGF- $\beta 1$ impairs the expression of luminal expressed HDPs by reducing the number of secretory cells that express these HDPs, which is not modulated by VD.

Modulation of Airway Host Defence

Responses by TGF- $\beta 1$ and VD stimuli compared to CNTRL were first calculated, followed by a log-transformation of the data. Data are presented as individual values, including means \pm SEM and were tested for significance using the two-way ANOVA and the Bonferroni post-hoc test $(n=$ 6 donors). b Confocal immunofluorescence staining of ciliated (a-tubulin), club (CC-16), goblet (MUC5AC) and basal cells (P63) in ALI-PBEC (of 1 donor, which was confirmed in 3 other donors), DAPI (blue) was used to stain the nuclei and antibodies (Table 2) were used for the detection of luminal cell markers (green) and basal cells (P63, red), respectively. ${ }^{* *} p<0.01,{ }^{* * *} p<0.001$. YWHAZ, tyrosine 3-monooxygenase/tryptophan 5-monooxygenase activation protein zeta; RPL27, ribosomal protein L27.

\section{Discussion}

Here we demonstrate that TGF- $\beta 1$ affects VD metabolism by increasing the expression of the VD-degrading enzyme CYP24A1 and reduces the VD-mediated expression of the HDP hCAP18/LL37 in both submerged undifferentiated PBEC and in differentiated ALI-PBEC. Moreover, TGF- $\beta 1$ also reduces the baseline expression of hCAP18/LL-37 via its ability to reduce the expression of $\mathrm{C} / \mathrm{EBP} \alpha$. In fully differentiated ALI-PBEC, TGF- $\beta 1$ represses the expression of constitutively expressed HDPs such as SLPI, s/lPLUNC and pIgR, which might in part be attributed to decreases in the number of secretory club and goblet cells. Treatment with VD did not counteract 
these effects of TGF- $\beta 1$ on HDP expression and epithelial differentiation.

To the best of our knowledge, we are the first to show that TGF- $\beta 1$ affects VD metabolism by increasing the expression of the VD-degrading enzyme CYP24A1, although an earlier study using hepatic cells did show an association between CYP24A1 and TGF- $\beta 1$ expression [24]. The involvement of CYP24A1 in the TGF- $\beta 1$ induced decrease in VD-mediated expression of hCAP18/LL-37 was confirmed by inhibiting its activity by KTZ. Since KTZ also inhibits other CYP-enzymes such as CYP27B1, we used $1,25(\mathrm{OH})_{2} \mathrm{D}_{3}$ to avoid the inhibitory effects of $\mathrm{KTZ}$ on the conversion of $25(\mathrm{OH})$ D3 into $1,25(\mathrm{OH})_{2} \mathrm{D}_{3}$ by CYP27B1. These TGF- $\beta 1$ mediated effects on CYP241 help to explain the inhibitory effects of TGF- $\beta 1$ on VD-induced expression of hCAP18/LL-37 in both undifferentiated and differentiated PBEC. We observed no changes in CYP27B1 expression and minor changes in $V D R$ expression after TGF- $\beta 1$ treatment, whereas a study in colon cancer cells showed that $V D R$ expression was repressed by Snail1 and Snail 2 that are known TGF- $\beta 1$-inducible transcription factors [52]. Prior to our findings, Kulkarni et al. [53] demonstrated that TGF- $\beta 1$ reduces baseline expression as well as phenylbutyrate-mediated increases in CAMP mRNA expression in a bronchial epithelial cell line, which was reversed by SB421543, an inhibitor of the canonical TGF- $\beta$-Smad signaling pathway. In line with this, we confirmed that SB421543 also reduced the TGF- $\beta 1$-mediated increase in CYP24A1 expression. Furthermore, VD-mediated expression of CAMP was even further enhanced when SB421543 was added, suggesting that VD-mediated CAMP expression was negatively affected by endogenous TGF- $\beta$ activity. We examined the underlying mechanisms of TGF- $\beta 1$-mediated inhibition of baseline CAMP expression and demonstrated that TGF- $\beta 1$ repressed mRNA expression of the transcription factor CEBPA. We furthermore demonstrated the relevance of this transcription factor by inhibition of CEBPA using siRNA, which resulted in a decrease of $C A M P$. TGF- $\beta 1$ further repressed the expression of CEBPA and CAMP in siRNA treated cells. The importance of $\mathrm{C} / \mathrm{EBP} \alpha$ in the VD-independent induction of hCAP18/LL-37 (CAMP) expression was previously demonstrated by Park et al. in keratinocytes [47]. Unexpectedly, siRNA-mediated inhibition of CEBPA also inhibited the expression of CYP24A1. By excluding the possibility that $C E B P B$ was also targeted by siRNA, we conclude that $C Y P 24 A 1$ expression may have been indirectly affected by TGF- $\beta 1$.
In addition to alterations in VD metabolism and effects, TGF- $\beta 1$ was also found to reduce the number of luminal secretory cells, possibly via initiation of EMT, and impaired expression of constitutively expressed HDPs SLPI and pIgR, which is in line with previous findings $[31,39,50]$. We are, however, the first to report that TGF- $\beta 1$ decreases the expression of the constitutively expressed HDP s/lPLUNC. We have recently demonstrated that expression of these constitutively expressed host defense mediators was also impaired following chronic CSexposure, which was accompanied by a selective reduction of differentiation into specialized airway epithelial cells [40]. Since CS-exposure is also known to increase the expression of TGF- $\beta 1$ in airway epithelial cells [30, 31], we consider the possibility that the CS-induced repression of constitutive expressed HDPs in airway epithelial cells is in part mediated via the induction of TGF- $\beta 1$. Interestingly and in line with our finding that TGF- $\beta 1$ decreases the number of club and goblet cells, Gohy et al. reported correlations between a TGF- $\beta 1$-mediated decrease of pIgR, epithelial dedifferentiation, and increased expression of mesenchymal markers [31]. It is important to consider that TGF- $\beta 1$ only alters differentiation markers at concentrations above $0.5 \mathrm{ng} / \mathrm{ml}$, as shown by Harrop et al [54]. Additionally, they demonstrated that expression of MUC5AC and MUC5B in differentiated PBEC was decreased by TGF- $\beta 2$, which is another TGF$\beta$-isoform and uses the same receptors [54]. In contrast to other studies showing inhibition of TGF- $\beta 1$-mediated effects on EMT by VD $[35,36]$, we have not observed any ameliorating effects of VD on TGF- $\beta 1$-mediated effects on the expression of SLPI, s/lPLUNC and pIgR, nor on the expression of secretory cell markers. This may be explained by the fact that we used differentiated primary airway epithelial cells, where VD activity may be more efficiently inhibited by TGF- $\beta 1$, or by the possibility that autocrine expression or processing of secreted immature TGF- $\beta 1$ might be more efficient in differentiated primary epithelial cells than in bronchial epithelial cell lines. The underlying mechanism for this difference needs to be further elucidated, for example, by comparing CYP24A1 levels, autocrine production of TGF- $\beta 1$, expression of TGF- $\beta$-receptors or extracellular activation of TGF- $\beta 1$ between cell lines and differentiated primary cells.

One of the strengths of this study is that we used differentiated primary airway epithelial cells that were obtained from multiple donors, instead of tumor-derived or immortalized airway epithelial cell lines, thereby increasing the relevance of our findings. It needs to be noted that PBEC used in this study were not derived from healthy
86

J Innate Immun 2020;12:74-89 DOI: $10.1159 / 000497415$
Schrumpf/Ninaber/van der Does/ Hiemstra 
donors, but from healthy parts of lung tissue derived from patients who have often smoked and underwent lung resection surgery for lung cancer. However, we have previously demonstrated that these cells differentiate into ciliated-, club and goblet cells similar to healthy individuals, develop a strong epithelial barrier and that expression of constitutively expressed HDPs and airway epithelial differentiation between donors with and without COPD do not differ [40]. This was in contrast to the findings by Gohy et al. [51], who showed that features of EMT persist in PBEC derived from COPD patients, most likely as they used material from patients with more severe stages of COPD.

This study also has a few limitations. First, we were not able to detect hCAP18/LL-37 peptide in apical washes of the stimulated PBEC using Western blot analysis, which is in line with our previous study [5]. Therefore, we used pooled and concentrated basal medium, and in line with our previous report detected a hCAP18/LL-37 immunoreactive peptide of $14 \mathrm{kDa}$ size, and did not detect the 4.5 $\mathrm{kDa}$ mature antimicrobial peptide LL-37. Levels of this peptide were increased by VD and reduced by TGF- $\beta 1$. Another limitation of this study is that we were not able to fully confirm TGF- $\beta 1$-mediated decreases in HDPs at the functional level by measuring the antibacterial activity against NTHi. As hCAP18/LL-37, SLPI and s/lPLUNC also have other activities such as anti-biofilm, immunomodulatory, and anti-protease activities in addition to their antibacterial activities [55-57], a more complex culture model using a combination of immune cells and airway epithelial cells might be relevant as an alternative approach to establish the consequences of these changes on host defense.

To extend the relevance of our findings to the situation in vivo, further studies are required to compare lung tissue levels of CYP24A1, 1,25(OH $)_{2} \mathrm{D}_{3}$ and expression of these HDPs in healthy donors and donors with chronic inflammatory lung disease or fibrosis. We showed that TGF- $\beta 1$ reduces the number of club cells, which is in line with the observations in diseases associated with both elevated TGF- $\beta 1$-levels and reduced numbers of club cells such as COPD, asthma, and bronchiolitis obliterans syndrome $[46,58,59]$. A contribution of TGF- $\beta 1$ to the pathogenesis of COPD is supported by findings of 2 studies showing that TGF- $\beta 1$ levels correlated with disease severity and airflow limitation in COPD patients $[27,60]$. In addition, TGF- $\beta 1$ expression was higher in airway epithelium of smokers with COPD compared to smokers without COPD $[26,27]$. To date, no treatment is available for COPD patients that selectively targets the harmful effects of TGF- $\beta 1$, without affecting the beneficial effects of TGF- $\beta 1$. Clinical trials that investigated the use of global inhibitors of TGF- $\beta$ signaling in oncology or in idiopathic pulmonary fibrosis showed that these compounds are frequently associated with adverse (health) effects and limited clinical benefit [61]. Drugs such as pirfenidone that block downstream TGF- $\beta$ pathways without affecting the immune system might be a better approach, and showed promising results in clinical trials in idiopathic pulmonary fibrosis $[61,62]$. Our study additionally suggests that VD is not a candidate to ameliorate the negative effects of TGF- $\beta 1$ on airway host defense.

In conclusion, we have shown that TGF- $\beta 1$ reduces the host defense of airway epithelial cells by impairing the VD-mediated expression of HDPs as well as constitutively expressed luminal HDPs such as SLPI and s/ IPLUNC and pIgR. We have additionally shown that TGF- $\beta 1$ reduces the number of secretory club and goblet cells, which might have additional consequences for host defense. We furthermore conclude that TGF- $\beta 1$ reduces the VD-mediated expression of hCAP18/LL-37 via a dual mechanism: directly by reducing the expression of an important transcription factor for hCAP18/LL-37 and indirectly via increasing of CYP24A1 that promotes the degradation of VD. These findings may have implications on our understanding of the role of TGF- $\beta 1$ in COPD by extending the range of mechanisms affected by TGF- $\beta 1$.

\section{Acknowledgements}

We would like to thank the departments of Microbiology and Infectious Diseases for their help and allowing us to use their laboratories for the culturing of NTHi and for performing antibacterial assays, respectively.

\section{Statement of Ethics}

Use of lung tissue that became available for research within the framework of patient care was in line with the "Human Tissue and Medical Research: Code of conduct for responsible use" (2011; www.federa.org) that describes the no-objection system for coded anonymous further use of such tissue. Therefore, individual written or verbal consent is not applicable.

\section{Disclosure Statement}

The authors have no conflicts of interest to declare. 


\section{Funding Sources}

This study was supported by a grant from the Lung Foundation Netherlands (grant \# 5.1.13.033) and a Marie Curie Intra-European Fellowship (grant \#622815).

\section{Author Contributions}

Conception and design: J.S., A.D., P.S.; Analysis and interpretation: J.S., D.N., A.D., P.S.; Drafting the manuscript for important intellectual content: J.S., A.D., P.S.; all authors have reviewed the manuscript and agree with its submission.

\section{References}

1 Sethi S. Infection as a comorbidity of COPD. Eur Respir J. 2010 Jun;35(6):1209-15.

2 Sethi S, Maloney J, Grove L, Wrona C, Berenson CS. Airway inflammation and bronchial bacterial colonization in chronic obstructive pulmonary disease. Am J Respir Crit Care Med. 2006 May;173(9):991-8.

3 De Rose V, Molloy K, Gohy S, Pilette C, Greene CM. Airway Epithelium Dysfunction in Cystic Fibrosis and COPD. Mediators Inflamm. 2018 Apr;2018:1309746.

$4 \mathrm{http}: / /$ goldcopd.org/wp-content/uploads/2016/12/wms-GOLD-2017-PocketGuide.pdf. 2017.

5 Amatngalim GD, Schrumpf JA, Henic A, Dronkers E, Verhoosel RM, Ordonez SR, et al. Antibacterial Defense of Human Airway Epithelial Cells from Chronic Obstructive Pulmonary Disease Patients Induced by Acute Exposure to Nontypeable Haemophilus influenzae: Modulation by Cigarette Smoke. J Innate Immun. 2017;9(4):359-74.

6 Raju SV, Lin VY, Liu L, McNicholas CM, Karki S, Sloane PA, et al. The Cystic Fibrosis Transmembrane Conductance Regulator Potentiator Ivacaftor Augments Mucociliary Clearance Abrogating Cystic Fibrosis Transmembrane Conductance Regulator Inhibition by Cigarette Smoke. Am J Respir Cell Mol Biol. 2017 Jan;56(1):99-108.

7 Hiemstra PS, McCray PB Jr, Bals R. The innate immune function of airway epithelial cells in inflammatory lung disease. Eur Respir J. 2015 Apr;45(4):1150-62.

8 Hancock RE, Haney EF, Gill EE. The immunology of host defence peptides: beyond antimicrobial activity. Nat Rev Immunol. 2016 May;16(5):321-34.

9 Amatngalim GD, Hiemstra PS. Airway Epithelial Cell Function and Respiratory Host Defense in Chronic Obstructive Pulmonary Disease. Chin Med J (Engl). 2018 May;131(9): 1099-107.

10 Evans SE, Xu Y, Tuvim MJ, Dickey BF. Inducible innate resistance of lung epithelium to infection. Annu Rev Physiol. 2010;72(1):41335.

11 Wang TT, Nestel FP, Bourdeau V, Nagai Y, Wang Q, Liao J, et al. Cutting edge: 1,25-dihydroxyvitamin D3 is a direct inducer of antimicrobial peptide gene expression. J Immunol. 2004 Sep;173(5):2909-12.

12 Christakos S, Dhawan P, Verstuyf A, Verlinden L, Carmeliet G. Vitamin D: Metabolism,
Molecular Mechanism of Action, and Pleiotropic Effects. Physiol Rev. 2016 Jan;96(1): 365-408.

13 Heulens N, Korf H, Janssens W. Innate immune modulation in chronic obstructive pulmonary disease: moving closer toward vitamin D therapy. J Pharmacol Exp Ther. 2015 May;353(2):360-8.

14 Martineau AR, James WY, Hooper RL, Barnes NC, Jolliffe DA, Greiller CL, et al. Vitamin D3 supplementation in patients with chronic obstructive pulmonary disease ( $\mathrm{ViDiCO}$ ): a multicentre, double-blind, randomised controlled trial. Lancet Respir Med. 2015 Feb; 3(2):120-30.

15 Lehouck A, Mathieu C, Carremans C, Baeke F, Verhaegen J, Van Eldere J, et al. High doses of vitamin $\mathrm{D}$ to reduce exacerbations in chronic obstructive pulmonary disease: a randomized trial. Ann Intern Med. 2012 Jan; 156(2):105-14.

16 Martineau AR, Jolliffe DA, Hooper RL, Greenberg L, Aloia JF, Bergman P, et al. Vitamin D supplementation to prevent acute respiratory tract infections: systematic review and meta-analysis of individual participant data. BMJ. 2017 Feb;356:i6583.

17 Wang Z, Zhang H, Sun X, Ren L. The protective role of vitamin D3 in a murine model of asthma via the suppression of TGF- $\beta / \mathrm{Smad}$ signaling and activation of the $\mathrm{Nrf} 2 / \mathrm{HO}-1$ pathway. Mol Med Rep. 2016 Sep;14(3): 2389-96.

18 Ramos-Martínez E, López-Vancell MR, Fernández de Córdova-Aguirre JC, RojasSerrano J, Chavarría A, Velasco-Medina A, et al. Reduction of respiratory infections in asthma patients supplemented with vitamin $\mathrm{D}$ is related to increased serum IL-10 and IFN $\gamma$ levels and cathelicidin expression. Cytokine. 2018 Aug;108:239-46.

19 DiFranco KM, Mulligan JK, Sumal AS, Diamond G. Induction of CFTR gene expression by $1,25(\mathrm{OH}) 2$ vitamin $\mathrm{D} 3,25 \mathrm{OH}$ vitamin $\mathrm{D} 3$, and vitamin D3 in cultured human airway epithelial cells and in mouse airways. J Steroid Biochem Mol Biol. 2017 Oct;173:323-32.

20 Hansdottir S, Monick MM, Hinde SL, Lovan N, Look DC, Hunninghake GW. Respiratory epithelial cells convert inactive vitamin D to its active form: potential effects on host defense. J Immunol. 2008 Nov;181(10):7090-9.

21 Wang TT, Tavera-Mendoza LE, Laperriere D, Libby E, MacLeod NB, Nagai Y, et al. Large- scale in silico and microarray-based identification of direct 1,25-dihydroxyvitamin D3 target genes. Mol Endocrinol. 2005 Nov; 19(11):2685-95.

22 Schrumpf JA, van Sterkenburg MA, Verhoosel RM, Zuyderduyn S, Hiemstra PS. Interleukin 13 exposure enhances vitamin D-mediated expression of the human cathelicidin antimicrobial peptide 18/LL-37 in bronchial epithelial cells. Infect Immun. 2012 Dec; 80(12):4485-94.

23 Uh ST, Koo SM, Kim YK, Kim KU, Park SW, Jang AS, et al. Inhibition of vitamin d receptor translocation by cigarette smoking extracts. Tuberc Respir Dis (Seoul). 2012 Nov;73(5): 258-65.

24 Vuica A, Vukojević K, Ferhatović Hamzić L, Jerić M, Puljak L, Grković I, et al. Expression pattern of CYP24 in liver during ageing in long-term diabetes. Acta Histochem. 2016 Jun;118(5):486-95.

25 Solomon JD, Heitzer MD, Liu TT, Beumer JH, Parise RA, Normolle DP, et al. VDR activity is differentially affected by Hic- 5 in prostate cancer and stromal cells. Mol Cancer Res. 2014 Aug;12(8):1166-80.

26 Takizawa H, Tanaka M, Takami K, Ohtoshi T, Ito $\mathrm{K}$, Satoh $\mathrm{M}$, et al. Increased expression of transforming growth factor- $\beta 1$ in small airway epithelium from tobacco smokers and patients with chronic obstructive pulmonary disease (COPD). Am J Respir Crit Care Med. 2001 May;163(6):1476-83.

27 de Boer WI, van Schadewijk A, Sont JK, Sharma HS, Stolk J, Hiemstra PS, et al. Transforming growth factor $\beta 1$ and recruitment of macrophages and mast cells in airways in chronic obstructive pulmonary disease. Am J Respir Crit Care Med. 1998 Dec;158(6):1951-7.

28 Papaporfyriou A, Loukides S, Kostikas K, Simoes DC, Papatheodorou G, Konstantellou $\mathrm{E}$, et al. Increased levels of osteopontin in sputum supernatant in patients with COPD. Chest. 2014 Oct;146(4):951-8.

29 Di Stefano A, Sangiorgi C, Gnemmi I, Casolari P, Brun P, Ricciardolo FL, et al. TGF- $\beta$ Signaling Pathways in Different Compartments of the Lower Airways of Patients With Stable COPD. Chest. 2018 Apr;153(4):85162.

30 Milara J, Peiró T, Serrano A, Cortijo J. Epithelial to mesenchymal transition is increased in patients with COPD and induced by cigarette smoke. Thorax. 2013 May;68(5):410-20. 
31 Gohy ST, Detry BR, Lecocq M, Bouzin C, Weynand BA, Amatngalim GD, et al. Polymeric immunoglobulin receptor down-regulation in chronic obstructive pulmonary disease. Persistence in the cultured epithelium and role of transforming growth factor- $\beta$. Am J Respir Crit Care Med. 2014 Sep;190(5):50921.

32 Thomas BJ, Kan-O K, Loveland KL, Elias JA, Bardin PG. In the Shadow of Fibrosis: Innate Immune Suppression Mediated by Transforming Growth Factor- $\beta$. Am J Respir Cell Mol Biol. 2016 Dec;55(6):759-66.

33 Worthington JJ, Fenton TM, Czajkowska BI, Klementowicz JE, Travis MA. Regulation of TGF $\beta$ in the immune system: an emerging role for integrins and dendritic cells. Immunobiology. 2012 Dec;217(12):1259-65.

34 Churg A, Tai H, Coulthard T, Wang R, Wright JL. Cigarette smoke drives small airway remodeling by induction of growth factors in the airway wall. Am J Respir Crit Care Med. 2006 Dec;174(12):1327-34.

35 Jiang F, Yang Y, Xue L, Li B, Zhang Z. $1 \alpha, 25$ dihydroxyvitamin D3 Attenuates TGF- $\beta$ Induced Pro-Fibrotic Effects in Human Lung Epithelial Cells through Inhibition of Epithelial-Mesenchymal Transition. Nutrients. 2017 Sep;9(9):980.

36 Fischer KD, Agrawal DK. Vitamin D regulating TGF- $\beta$ induced epithelial-mesenchymal transition. Respir Res. 2014 Nov;15(1):146.

37 Tan ZX, Chen YH, Xu S, Qin HY, Zhang C, Zhao H, et al. Calcitriol inhibits bleomycininduced early pulmonary inflammatory response and epithelial-mesenchymal transition in mice. Toxicol Lett. 2016 Jan;240(1): $161-71$.

38 Bedke N, Sammut D, Green B, Kehagia V, Dennison P, Jenkins G, et al. Transforming growth factor-beta promotes rhinovirus replication in bronchial epithelial cells by suppressing the innate immune response. PLoS One. 2012;7(9):e44580.

39 Jaumann F, Elssner A, Mazur G, Dobmann S, Vogelmeier C; Munich Lung Transplant Group. Transforming growth factor-betal is a potent inhibitor of secretory leukoprotease inhibitor expression in a bronchial epithelial cell line. Eur Respir J. 2000 Jun;15(6):1052-7.

40 Amatngalim GD, Schrumpf JA, Dishchekenian F, Mertens TC, Ninaber DK, van der Linden AC, et al. Aberrant epithelial differentiation by cigarette smoke dysregulates respiratory host defence. Eur Respir J. 2018 Apr; 51(4):1701009.
41 Agerberth B, Grunewald J, Castaños-Velez E, Olsson B, Jörnvall $\mathrm{H}$, Wigzell $\mathrm{H}$, et al. Antibacterial components in bronchoalveolar lavage fluid from healthy individuals and sarcoidosis patients. Am J Respir Crit Care Med. 1999 Jul;160(1):283-90.

42 van Wetering S, van der Linden AC, van Sterkenburg MA, Rabe KF, Schalkwijk J, Hiemstra PS. Regulation of secretory leukocyte proteinase inhibitor (SLPI) production by human bronchial epithelial cells: increase of cell-associated SLPI by neutrophil elastase. J Investig Med. 2000 Sep;48(5):359-66.

43 Schrumpf JA, Amatngalim GD, Veldkamp JB, Verhoosel RM, Ninaber DK, Ordonez SR, et al. Proinflammatory Cytokines Impair Vitamin D-Induced Host Defense in Cultured Airway Epithelial Cells. Am J Respir Cell Mol Biol. 2017 Jun;56(6):749-61.

44 Schuster I, Egger H, Nussbaumer P, Kroemer RT. Inhibitors of vitamin D hydroxylases: structure-activity relationships. J Cell Biochem. 2003 Feb;88(2):372-80.

45 Loose DS, Kan PB, Hirst MA, Marcus RA, Feldman D. Ketoconazole blocks adrenal steroidogenesis by inhibiting cytochrome P450dependent enzymes. J Clin Invest. 1983 May; 71(5):1495-9.

46 Aschner Y, Downey GP. Transforming Growth Factor- $\beta$ : Master Regulator of the Respiratory System in Health and Disease. Am J Respir Cell Mol Biol. 2016 May;54(5):647-55.

47 Park K, Elias PM, Oda Y, Mackenzie D, Mauro T, Holleran WM, et al. Regulation of cathelicidin antimicrobial peptide expression by an endoplasmic reticulum (ER) stress signaling, vitamin $\mathrm{D}$ receptor-independent pathway. J Biol Chem. 2011 Sep;286(39): 34121-30.

48 Li R, Liang L, Dou Y, Huang Z, Mo H, Wang $Y$, et al. Mechanical stretch inhibits mesenchymal stem cell adipogenic differentiation through TGF $\beta 1 /$ Smad2 signaling. J Biomech. 2015 Oct;48(13):3665-71.

49 Veldurthy V, Wei R, Campbell M, Lupicki K, Dhawan P, Christakos S. 25-Hydroxyvitamin $\mathrm{D}_{3}$ 24-Hydroxylase: A Key Regulator of $1,25(\mathrm{OH})_{2} \mathrm{D}_{3}$ Catabolism and Calcium Homeostasis. Vitam Horm. 2016;100:137-50.

50 Påhlman LI, Jögi A, Gram M, Mori M, Egesten A. Hypoxia down-regulates expression of secretory leukocyte protease inhibitor in bronchial epithelial cells via TGF- $\beta 1$. BMC Pulm Med. 2015 Mar;15(1):19.

51 Gohy ST, Hupin C, Fregimilicka C, Detry BR, Bouzin C, Gaide Chevronay H, et al. Imprint- ing of the COPD airway epithelium for dedifferentiation and mesenchymal transition. Eur Respir J. 2015 May;45(5):1258-72.

52 Larriba MJ, Bonilla F, Muñoz A. The transcription factors Snail1 and Snail2 repress vitamin $\mathrm{D}$ receptor during colon cancer progression. J Steroid Biochem Mol Biol. 2010 Jul;121(1-2):106-9.

53 Kulkarni NN, Yi Z, Huehnken C, Agerberth $\mathrm{B}$, Gudmundsson GH. Phenylbutyrate induces cathelicidin expression via the vitamin D receptor: linkage to inflammatory and growth factor cytokines pathways. Mol Immunol. 2015 Feb;63(2):530-9.

54 Harrop CA, Gore RB, Evans CM, Thornton DJ, Herrick SE. TGF- $\beta_{2}$ decreases baseline and IL-13-stimulated mucin production by primary human bronchial epithelial cells. Exp Lung Res. 2013 Feb;39(1):39-47.

55 Gakhar L, Bartlett JA, Penterman J, Mizrachi $\mathrm{D}$, Singh PK, Mallampalli RK, et al. PLUNC is a novel airway surfactant protein with antibiofilm activity. PLoS One. 2010 Feb;5(2): e9098.

56 Twigg MS, Brockbank S, Lowry P, FitzGerald SP, Taggart C, Weldon S. The Role of Serine Proteases and Antiproteases in the Cystic Fibrosis Lung. Mediators Inflamm. 2015;2015: 293053.

57 van der Does AM, Bergman P, Agerberth B, Lindbom L. Induction of the human cathelicidin LL-37 as a novel treatment against bacterial infections. J Leukoc Biol. 2012 Oct; 92(4):735-42.

58 DerHovanessian A, Weigt SS, Palchevskiy V, Shino MY, Sayah DM, Gregson AL, et al. The role of TGF- $\beta$ in the association between primary graft dysfunction and bronchiolitis obliterans syndrome. Am J Transplant. 2016 Feb;16(2):640-9.

59 Hiemstra PS, Bourdin A. Club cells, CC10 and self-control at the epithelial surface. Eur Respir J. 2014 Oct;44(4):831-2.

60 Chiang $\mathrm{CH}$, Chuang CH, Liu SL. Transforming growth factor- $\beta 1$ and tumor necrosis factor- $\alpha$ are associated with clinical severity and airflow limitation of COPD in an additive manner. Lung. $2014 \mathrm{Feb}$;192(1):95-102.

61 Lachapelle P, Li M, Douglass J, Stewart A. Safer approaches to therapeutic modulation of TGF- $\beta$ signaling for respiratory disease. Pharmacol Ther. 2018 Jul;187:98-113.

62 Rafii R, Juarez MM, Albertson TE, Chan AL A review of current and novel therapies for idiopathic pulmonary fibrosis. J Thorac Dis. 2013 Feb;5(1):48-73.
Modulation of Airway Host Defence

Responses by TGF- $\beta 1$ and VD
J Innate Immun 2020;12:74-89

DOI: $10.1159 / 000497415$ 